FACTA UNIVERSITATIS

Series: Linguistics and Literature Vol. 16, $\mathrm{N}^{\mathrm{o}} 1,2018$, pp. 25-37

https://doi.org/10.22190/FULL1801025O

Original Scientific Paper

\title{
A LEXEME-BASED STUDY OF THE AGENTIVE FRENCH SUFFIXES -ANT, - EUR AND -ISTE \\ UDC 811.133.1'366
}

\author{
Samuel T. Owoeye ${ }^{1}$, Olukayode T. Babatunde ${ }^{2}$ \\ ${ }^{1}$ Covenant University, Ota, Nigeria, ${ }^{2}$ Landmark University, Omuaran, Nigeria
}

\begin{abstract}
Construction Morphology which is fast becoming an alternative term to Derivational Morphology is known to be rooted in Lexeme-Based Morphology and is noted for its Lexeme Formation Rules that are formulated to account for the construction of existing derivational words which serve as models for the creation of other yet-to-beattested words in human languages. The advent of Lexeme-Based Morphology is as a result of the inability of morpheme-based models to adequately account for some morphologically derived words. Proponents of lexeme-based morphology, hence, believe that it is more appropriate to analyze morphologically formed words when lexemes are seen as the basic units of morphological operation. It is in the light of this hypothesis that we set out in this paper to do a lexeme-based study of the agentive French suffixes -ant, eur and-iste in order to examine its analytical adequacy. After a careful analysis, the study reveals that the lexeme-based approach to construction morphology seems to be more adequate than the morpheme-based approach.
\end{abstract}

Key words: lexeme, lexeme-based morphology, French agent nouns, lexeme formation rule, base modification

\section{INTRODUCTION}

Apart from the theoretical debates on the autonomy of morphological analysis generated by the Lexicalist Hypothesis in the 1970s, there is also a much recent categorisation of morphological theories into Morpheme-Based and Lexeme-Based models. The majority of the morphological theories formulated towards the end of the $20^{\text {th }}$ century were hence either morpheme-based or lexeme-based, described in French by Fradin (2003) respectively as Morphologie Morphémique Combinatoire (Combinatory

Submitted July 7 2017, accepted for publication April 4, 2018

Corresponding author: Samuel Tuesday Owoeye

Covenant University, Nigeria

E-mail: sam.owoeye@ covenantuniversity.edu.ng 
Morpheme-based Morphology, in English) and Morphologie Lexématique Classique (Classical Lexeme-based Morphology, in English). The primary distinction between the two lies in the conception of the linguistic status of 'the smallest significant unit' and the combinatory processes of morphological construction. While morpheme-based theories adopt the morpheme as the smallest unit, lexeme-based theories see the lexeme as the smallest unit. Consequently, the former consider the formation of complex words as a simple concatenation of isomorphic morphemes, while the latter rely on Word Formation Rules (WFR henceforth) also known as Lexeme Formation Rules (LFR henceforth) or Lexeme Construction Rules (LCR henceforth).

In this study, we embark on an examination of the adequacy of the lexeme-based morphological analysis taking as a case study the French agentive -ant, -eur and -iste suffixes. We begin by providing a brief literature review on the French suffixes under examination as it relates to the notion of morphological agentivity. At the core of the study, we examine the underlying principles of lexeme-based morphology and use its rules to analyze the construction of agent nouns arising from the three suffixes. In so doing, the inadequacy of Morpheme-Based Morphology (MBM henceforth) in accounting for base modifications in some constructed words is identified.

\section{AGENTIVITY AND THE FRENCH SUFFIXES - ANT, -EUR AND -ISTE}

The three suffixes - ant, -eur and-iste are agentive in the sense that each of them has been used to form agent nouns. What constitutes agentivity in morphology has been addressed by experts. According to Fradin and Kerleroux (2003: 77), referring to the works of Fillmore, (1982); Foley and Van Valin (1984); Dowty (1991), an agentive argument must possess at least one of the proto-agentive properties, which include the following:

i. transitive verbs

ii. verbs with causative implication

iii. nouns denoting activities

iv. nouns denoting entities that are apparently artifacts.

More precisely, citing Dowty (1991), an argument is said to be proto-agentive if it satisfies at least one of the following proto-agentive principles:

i. strong agentivity i.e. (a) the agent is voluntarily involved in an activity. e.g. contestant (contestant), chanteur (singer), idéologiste (ideologist); (b) the agent is the cause of a social activity, e.g. fabricant (maker), tueur (killer), aliéniste (alienist).

ii. weak agentivity, i.e. the agent engages in a reflexive activity, e.g. arrivant (arriver), dormeur (sleeper).

It must be noted here that agentivity in morphology does not only apply to animate but also to inanimate objects. Some linguists such as Fillmore (1982), Cruse (1973), Aronoff (1976), Booij (1986) and Ulland (1993), opine that it is difficult to trace a morphological line of demarcation between agent nouns and names of instrument formed from agentive affixes. Aronoff (1976: 284), writing on the Word Formation Rule of the English -er suffixation notes that "whether a given instance of the agentive WFR X-er names an animate, inanimate, material, immaterial entity is independent of the rule itself: 
it is ascribed to pragmatic factors." Based on the foregoing, therefore, we have integrated, in this study, instruments such as adoucissant (sweetener), accelerateur (accelerator) and baliste (ballista) into agent nouns classification.

The French suffix - ant is originally the inflection that produces the present participle form of French verbs. It is however used to form adjectives and nouns (see Laporte, (1992: 31) and Grevisse (1993: 101)). While some linguists do not see this suffix as capable of producing agent nouns, some others consider it agentive. As remarked by Ulland (1993: 47), the nouns formed by using the suffix - ant are in reality not nouns because they are all first and foremost adjectives which are secondarily used nominally. The position of Ulland has been corroborated by Anscombre (2003 18) when he opined that "in other terms, this thesis postulates that while agent nouns in -eur refer to entities that are real and potential agents of a process, agent nous in -ant refer, on the contrary, to entities involved in the process, and not agents of this process" (our translation ${ }^{1}$ ).

In the same vein, Roy and Soare (2010: 35), while relying on the principles of transitivity, as elaborated by Dubois (1962) and Dubois and Dubois-Charlier (1999), affirms that the suffix - ant cannot produce agent nouns because the nous formed by it are generally based on intransitive verbs. However, the findings arising from the study conducted by Rosenberg (2008: 149) show that there are agent nouns formed and attested in contemporary French. She found out that the suffix -ant demonstrated similar polysemy hierarchy with the suffix - eur as shown below:

V-ant: Agent > Instrument $>$ Action > Résultat $>$ Locatif

V-eur: Agent $>$ Instrument $>$ Locatif/Action/Résultat

We align with Rosenberg in opining that the French suffix- ant is capable of producing agent nouns, as can be deduced from few examples that we have made earlier on.

In the case of the French suffix -eur, it can be traced to two Latin sources (Grevisse 1993: 212-213). The first source which is -orem is used to form some de-adjectival abstract feminine nouns indicating the quality of the base adjective. Words formed through this suffixation process include, for example, blancheur (whiteness), laideur (ugliness), longueur (length), hauteur (height), douceur (sweetness), grandeur (greatness), profondeur (deepness), froideur (coolness), lourdeur (heaviness). According to Grevisse (ibid), this suffixation system is "almost extinct today" and consequently, one can say that even if the nouns formed by it have not yet gone out of use, its availability for new words remains remote. The second Latin source of the suffix -eur (-euse or-eresse in its feminine form) is -atorem and is used mainly to form agent nouns from verbs or nouns that meet agentivity requirements. Primarily therefore, the suffix - eur attaches to verbs that possess either strong or weak agentivity. Secondarily, it combines with some nouns denoting perceptible activities to form agent nouns (e.g. noceur (reveller), footballeur (footballer), boxeur (boxer), catcheur (wrestler), farceur (prankster), camionneur (lorry-driver)). There exists also a scenario where the suffix -eur is added to verbs or nouns to form agent nouns referring to machines or apparatuses (e.g. chargeur (charger), ventilateur (ventilator), mitigeur (mixing valve)). Furthermore, the suffix -ateur (-atrice in its feminine form),

\footnotetext{
${ }^{1}$ En d'autres termes, cette thèse signifie qu'alors que les noms d'agent en -eur désignent desentités en tant qu'agents réels ou potentiels d'un procès, les noms d'agent en -ant renvoient à l'inverse à des entités cette fois prises dans le procès, et non agents de ce procès.
} 
which Grevisse (ibid) calls "la forme savante" of the agentive - eur combines with some verbs to form agent nouns which are also used adjectivally (e.g. mystificateur (hoaxer), provocateur (agitator), indicateur (indicator), secateurs (pruner), planificateur (planner).

Coming to the suffix -iste, the meaning that can be given to each of archiviste (archivist), gréviste (striker) and journaliste (journalist) suggests that this suffix can form agent nouns. Archiviste is someone who keeps archives, gréviste is someone who participates in a strike action and journaliste is someone whose profession is journalism. The agentive status of the suffix -iste can be said to have been confirmed in the remarks of Dubois et al. (2006: 433). According to them, the French suffix -iste arose from the Greek -ista which has five descriptions as enunciated below:

- who is of a particular system (anarchisme anarchiste formed on anarchie).

- who is of a particular conduct (absentéisme - absentéiste formed on absent).

- who is of a particular organization (cégétiste formed on C.G.T.).

- who does a particular activity (dentiste formed on dent).

- who is from a particular place (nordiste formed on nord)

In the light of the above descriptions by Dubois et al., Roché (2007: 46) identifies two semantic poles in the construction of derived nous from -iste. He calls the first pole a situation where there is an axiological relationship between the derived noun and its base which is always a verb, a noun or an adjective (esclavage - esclavagiste). He identifies the second pole whereby the noun so formed is both process-based and agent or either of the two (parachute - parachutiste). From the foregoing, it can be affirmed that the French suffix -iste qualifies to be labeled an agentive suffix just like -ant and - eur. Having established the agentive status of the three suffixes under examination, we now proceed to do a lexeme-based analysis of them.

\section{LEXEME-BASED MORPHOLOGICAL ANALYSIS}

Recent developments in Construction Morphology (CM henceforth) tend to favour a lexeme-based to the detriment of a morpheme-based analysis of morphologically derived words. The most critical argument against MBM as pointed out by the adherents of Lexeme-Based Morphology (LBM henceforth) is the linguistic status of sign accorded affixes and inflectional endings by MBM, whereby each of the signs is seen as an arbitrary union of sound and meaning. From the point of view of LBM, inflectional endings and affixes do not have any place in the lexicon, hence, they are not listed in dictionaries and therefore cannot constitute the smallest lexical signs. Consequently, in order to abandon the notion of morpheme, the term lexeme was introduced as the smallest lexical sign visible to morphology. By this approach, the morphologically segmentable and non-segmentable elements - affixes, inflectional endings, stem modifications, reduplication, revowelling, metathesis, subtraction etc. are mere exponents of phonological, syntactic and semantic regularity to which ideal speakers have recourse when forming intuitively complex lexemes from base lexemes through the mental operations of the LFRs.

To define the lexeme, the distinction between it and the term 'word form' established by Matthews (1974: 62) will suffice here. According to Matthews, the word form is an independent unit containing the morphosyntactic properties functioning as the atom of syntax, i.e. the units found in texts. As for the lexeme, it is the abstract correlate of the word-form, the morphological unit that has no inflectional marks. In French, for example, 
porte, portais, porté, porta (conjugated forms of the verb 'porter') are four distinct word forms (with inflectional properties) but four instantiations of a single lexeme porter (to carry). From the base lexeme porter, other complex lexemes such as portable (portable) and porteur (carrier), can be constructed by derivation. Unlike the MBM, which is a grammar of Item and Arrangement as earlier mentioned, LBM is a grammar of Item and Process (Hockett 1954:14) or of Word and Paradigm (Hockett 1954: 1).

Under LBM, LFRs are taken to be processes through which lexemes are selected according to phonological, syntactic and semantic characteristics of the base lexeme. This selection, which is a process of input and output, utilizes the phonological, syntactic and semantic properties of the base lexeme to produce another lexeme, itself possessing its own phonological, syntactic and semantic properties. As an example, we reproduce here a typical LFR proposed by Fradin (2003: 254) for agent noun formation:

\begin{tabular}{lll} 
& INPUT & OUTPUT \\
\hline (G) & BL & CL \\
$(\mathrm{F})$ & $/ \ldots \ldots /$ & $/ \ldots \ldots /$ \\
$(\mathrm{SX})$ & cat $: \mathrm{v}$ & cat $: \mathrm{n}$ \\
& $\operatorname{arg-st:~NP0~V~NP1}$ & someone who performs a social \\
$(\mathrm{S})$ & role: NP0 = agent & activity) \\
\hline
\end{tabular}

Fig. 1 Fradin's model of LFR.

Key: $\mathrm{G}=$ Autographic Information, $\mathrm{F}=$ Phonological Information, $\mathrm{SX}=$ Syntactic Information, $\mathrm{S}=$ Semantic Information, cat $=$ category, $\mathrm{v}=$ verb, $\mathrm{n}=$ noun, $\arg$-st $=$ argument structure, NP = Noun Phrase

Figure 1 presents the morphological rules from the point of view of LBM as multidimensional. While $\mathrm{G}$ gives information on the autographic concerns, the heading $\mathrm{F}$ provides information on the phonological form of the base lexeme (BL) as well as the constructed lexeme (CL). In the same order, SX and S represent the syntactic and semantic properties respectively. The SX contains information on the lexical category of the two lexemes involved, as well as the argument structure and the syntactic role of the base lexeme. The semantic details of both the input and the output are provide by S. Qualitatively, therefore, this rule shows that the construction of any agent noun using the suffix -eur requires a base verb that has an agentive argument structure, i.e. the base verb must have an agent as its subject in order to receive the suffix -eur. The analytical advantage this LFR has over a simple combinatory morpheme-based analysis is in the former's multidimensionality. While a morpheme-based morphologist would probably argue that mangeur (eater), for instance, is simply a biunique combination of the stem of manger (to eat) and the suffix -eur, a lexemebased rule will tell more than that by the given autographic, phonological, syntactic and semantic operations involved in the process of deriving mangeur from the verb manger.

In an attempt at making LFRs more generative, Owoeye (2013: 50) builds on Fradin's model by introducing into LFR formulation the notion of deep and surface structures of linguistic analysis. He suggests a LFR that can account for the construction of all agent nouns in French, not only those arising from the suffix - eur but also those from agentive suffixes such as -ant, -ier, -iste and -oir. An English version of that generative rule, by our own translation, is presented in Figure 2: 


\begin{tabular}{|c|c|c|}
\hline & INPUT & OUTPUT \\
\hline $\mathrm{G}$ & BL & CL \\
\hline $\mathrm{F}$ & $|\ldots \ldots|$. & $|\ldots|$. \\
\hline SX & $\begin{array}{l}\text { Cat-Surf: } \mathrm{V}_{t} / \mathrm{V}_{\text {int }} / \mathrm{N} \\
\text { DS: NP+Pred }\end{array}$ & Cat:N \\
\hline S & $\begin{array}{l}\text { Role: } \mathrm{NP}=\text { Agent } \\
\text { +activity } \\
\text { (+perceptible, } \pm \text { social) }\end{array}$ & $\begin{array}{l}\text { Role: } \mathrm{NP}=\text { Agent } \\
\text { +agent } \\
( \pm \text { animate }, \pm \text { inanimate, } \pm \text { partisan } \\
\pm \text { instrumental }, \pm \text { professional })\end{array}$ \\
\hline
\end{tabular}

Fig. 2 A Generative LFR for French Agentive Suffixation

Key:

G: Autographic Information

F: Phonological Information

SX: Syntactic Information

S: Syntactic Information

D-S: Deep Structure

BL: Base Lexeme

Cat- Surf: Surface Syntactic Category

Cat : Syntactic Category

CL: Constructed Lexeme

NP: Noun Phrase

Pred: Predicate $\mathrm{V}_{t} / \mathrm{V}_{\text {in }} / \mathrm{N}$ : Transitive Verb/ Intransitive Verb/Noun

The idea behind Owoeye's LFR model is that although a very large number of agent nous are derived from a transitive verb base, there are several others that are formed using an intransitive verb base, nominal and even adjectival base lexemes. He therefore notes that the base of every agent noun is essentially in the deep structure represented by a Noun Phrase plus a Predicate (NP+Pred). He further explains that this Deep Structure can appear on the Surface in the form of a transitive verb, an intransitive verb, a noun or an adjective. On the semantic side, he opines that only perceptible activity should form the basis for a base lexeme to attract any agentive suffix. This being the case, the social activity requirement relied on by Fradin in his model has been critically reviewed and modified. The modification becomes inevitable because agent nouns such as flâneur (loafer) and dormeur (sleeper) are derived from intransitive rather than transitive verbs. Social activity can only be linked to a transitive verb that attracts an object. Premised on the foregoing, the analysis that we embark on in the next section is based on the Owoeye's LFR model.

\section{APPLICATION OF OWOEYE'S LFR TO THE AGENTIVE-ANT,-EUR AND -ISTE SUFFIXATIONS}

An inventory from le Trésor de la Langue Française informatisé (TLFi), an online French lexical resource, shows that there are 64 entries of agent nouns formed using the suffix -ant distributed into 43 (68\%) (e.g. attaquant (attacker), fabricant (manufacturer), récitant (reciter)) constructed on transitive verbs, 14 (22\%) (e.g., arrivant (arriver), officiant (officiator), aboyant (barker)) on intransitive verbs and 6 (10\%) (analgésiant (analgesic), arabisant (arabist), romanisant (romanist)) on nominal bases. In the case of the suffix-eur, there are 1,194 entries. Out of this figure, 805 (67\%) (e.g. délivreur (deliverer), enfileur (stringer), niveleur (equalizer)) are derived from transitive verbs, 126 (11\%) (e.g. discoureur (talkative), galopeur (galloper), valseur (waltzer) from intransitive verbs and 71 (6\%) (e.g. adducteur (protractor) footballeur (footballer), mareyeur (fish merchant)) from nouns. The remaining 192 (16\%) are considered to be loan agent nouns from Latin which means that they 
are not originally constructed in French (e.g. exécuteur (executor), délateur (delator), préteur (pretor). The case of the suffix -iste is, however, different because agent nouns derived from it are predominantly from noun bases. Out of a total of 311 agent nous found in TLFi, only 5 (2\%) (e.g. aliéniste (alienist), armoriste (armorist)) are formed from transitive verbs. While $268(86 \%)$ (e.g. bâtonniste (cudgel) journaliste (journalist) ornemaniste (ornaments seller)) are formed using nominal bases, 38 (12\%) (e.g. centraliste (centralist), moderniste (modernist), sensualiste (sensualist)) are formed on adjectival bases. We did not find any -iste agent noun constructed on an intransitive verb.

The first scenario will be where a transitive verb serves as a base lexeme. We take one example from each of the three suffixes, apply the rule to them and the results are what we have in figures 3, 4 and 5 below:

\begin{tabular}{|c|c|c|}
\hline & INPUT & OUTPUT \\
\hline $\bar{G}$ & fabriquer & fabricant \\
\hline $\mathrm{F}$ & /fabrik/ & / fabrikã/ \\
\hline SX & Cat-Surf: $V_{t}$ & Cat:N \\
\hline S & $\begin{array}{l}\text { D-S: l'homme fabrique la } \\
\quad \text { voiture } \\
\text { Role: } \mathrm{NP}=\text { Agent } \\
\text { +activity } \\
\text { (+perceptible, +social) }\end{array}$ & $\begin{array}{l}\text { Role: } \mathrm{NP}=\text { Agent } \\
\text { +agent } \\
\text { (+animate) }\end{array}$ \\
\hline
\end{tabular}

Fig. 3 LFR for the construction of 'fabricant'

\begin{tabular}{lll}
\cline { 2 - 3 } & INPUT & OUTPUT \\
\hline $\mathrm{G}$ & délivrer & délivreur \\
$\mathrm{F}$ & /delivr/ & / delivrœe/ \\
$\mathrm{SX}$ & Cat-Surf $: \mathrm{V}_{t}$ & Cat: $\mathrm{N}$ \\
& D-S: 1'homme délivre son ami & \\
& Role: $\mathrm{NP}=$ Agent & Role: $\mathrm{NP}=$ Agent \\
$\mathrm{S}$ & +activity & +agent \\
& $(+$ perceptible,+ social $)$ & $(+$ animate $)$ \\
\hline
\end{tabular}

Fig. 4 LFR for the construction of 'délivreur'

\begin{tabular}{lll}
\cline { 2 - 3 } & INPUT & OUTPUT \\
\hline $\mathrm{G}$ & aliéner & aliéniste \\
$\mathrm{F}$ & /alien/ & /alienist/ \\
$\mathrm{SX}$ & Cat-Surf $: \mathrm{V}_{t}$ & Cat $: \mathrm{N}$ \\
& D-S: l'homme aliène son frère & \\
& Role: NP = Agent & Role $: \mathrm{NP}=$ Agent \\
$\mathrm{S}$ & +activity & +agent \\
& (+perceptible,, +social) & (+animate) \\
\hline
\end{tabular}

Fig. 5 LFR for the construction of 'aliéniste' 
As captured in Figures 3, 4 and 5, the rule pattern is the same for fabricant, délivreur and aliéniste. In fabricant, for example, the BL is fabriquer (to manufacture), for it to produce the CL, it has to go through a phonological process whereby the stem of the verb takes into consideration a phonotactic requirement of the French language. In the same manner, the BL requires a D-S which is here represented by a NP 'l'homme' (the man) plus a Pred. 'fabrique la voiture' (manufactures the car). It is the D-S that puts the transitive verb 'fabriquer' forward to serve as the Surface lexeme to form 'fabricant'. The semantic process involved here is that the verb base connotes an activity which is perceptible and at the same time social. The activity is social because the verb is transitive and can therefore attract a patient which is suggested here to be the 'la voiture' in the D-S. In order to verify the eventual construction of the agent noun, it must correspond to the NP in the D-S. Hence, 'l'homme' which is the NP playing the role of the agent in the D-S must be the same person as the agent noun constructed.

The second instance is where the BL on the Surface is an intransitive verb. Since there is no -iste agent noun arising from an intransitive verb, we are applying the LFR to only two examples here as shown in Figures 6 and 7:

\begin{tabular}{lll}
\cline { 2 - 3 } & INPUT & OUTPUT \\
\hline $\mathrm{G}$ & aboyer & aboyant \\
$\mathrm{F}$ & /aboy/ & /aboyã// \\
$\mathrm{SX}$ & Cat-Surf: $\mathrm{V}_{\text {int }}$ & Cat: $\mathrm{N}$ \\
& $\begin{array}{l}\text { D-S: } 1 \text { 'homme aboie } \\
\text { Role: NP = Agent }\end{array}$ & Role: NP = Agent \\
$\mathrm{S}$ & +activity & +agent \\
& (+perceptible, -social) & (+animate) \\
\hline
\end{tabular}

Fig. 6 LFR for the construction of 'aboyant'

\begin{tabular}{lll} 
& INPUT & OUTPUT \\
\hline $\mathrm{G}$ & Valser & Valseur \\
$\mathrm{F}$ & /vals/ & /valsœe / \\
$\mathrm{SX}$ & Cat-Surf: $\mathrm{V}_{\text {int }}$ & Cat:N \\
& D-S: 1'homme valse & \\
& Role: $\mathrm{NP}=$ Agent & Role: NP = Agent \\
$\mathrm{S}$ & +activity & +agent \\
& $(+$ perceptible, -social) & (+animate) \\
\hline
\end{tabular}

Fig. 7 LFR for the construction of 'valseur'

The rule patterns in both Figures 6 and 7 are the same because aboyant and valseur share similar syntactic characteristics, In the case of the construction of 'valseur', the BL is an intransitive verb as noted earlier. It can be seen from Figure 7 that the BL undergoes the same phonological operation as in the case of 'fabricant', 'délivreur' and 'aliéniste' in Figures 3, 4 and 5. However on the syntactic pole, the predicate of the D-S does not have an object. This is so because intransitive verbs do not attract objects. Nevertheless, the fact remains that the verb 'valser' (to dance to waltz music) denotes an activity that is perceptible even if it lacks social property. The agent noun 'valseur' is validly formed 
because it corresponds to the agent (i.e. the NP) in the D-S. The construction of agent nouns such as 'valseur' can be associated with Dowty's (1991) weak agentivity as cited earlier in this study.

Another scenario in the construction of agent nouns arising from suffixes -ant, -eur and -iste is where a noun serves as the BL on the Surface. We apply the same LFR to the formation of arabisant, adducteur and ornemaniste which are constructed respectively on the nouns arabe, adduction, ornament.

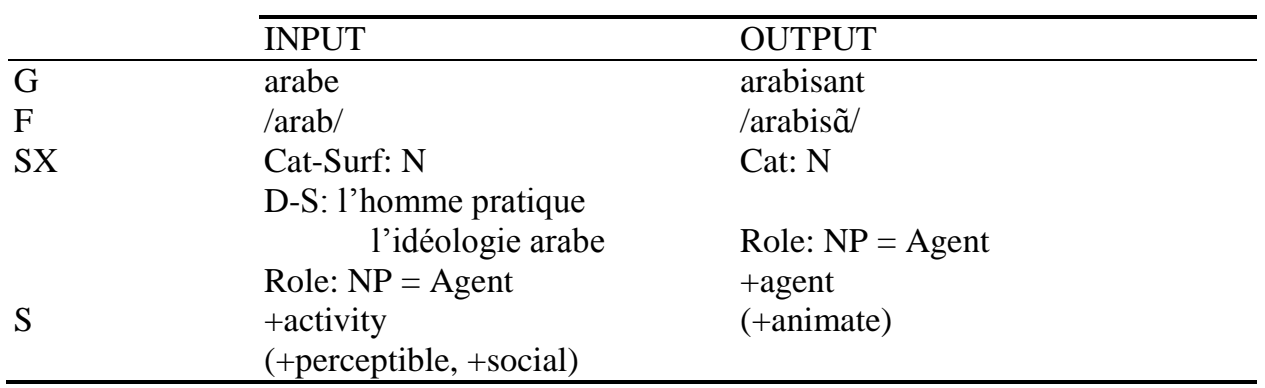

Fig. 8 LFR for the construction of 'arabisant'

\begin{tabular}{lll}
\cline { 2 - 3 } & INPUT & OUTPUT \\
\hline $\mathrm{G}$ & adduction & adducteur \\
$\mathrm{F}$ & /adykt/ & /adyktœR/ \\
$\mathrm{SX}$ & Cat-Surf: $\mathrm{N}$ & Cat: $\mathrm{N}$ \\
& D-S: l'objet faire l'adduction & \\
& Role: $\mathrm{NP}=$ Agent & Role: $\mathrm{NP}=$ Agent \\
& +activity & +agent \\
$\mathrm{S}$ & $(+$ perceptible,+ social $)$ & (+inanimate) \\
\hline
\end{tabular}

Fig. 9 LFR for the construction of 'adducteur'

\begin{tabular}{|c|c|c|}
\hline & INPUT & OUTPUT \\
\hline$\overline{\mathrm{G}}$ & ornement & ornemaniste \\
\hline $\mathrm{F}$ & /oRnəmã/ & /oRnomanist/ \\
\hline SX & Cat-Surf: N & Cat: N \\
\hline $\mathrm{S}$ & $\begin{array}{l}\text { D-S: l'homme vend des } \\
\quad \text { ornements } \\
\text { Role: NP = Agent } \\
\text { +activity } \\
\text { (+perceptible, +social) }\end{array}$ & $\begin{array}{l}\text { Role: } \mathrm{NP}=\text { Agent } \\
\text { +agent } \\
\text { (+inanimate) }\end{array}$ \\
\hline
\end{tabular}

Fig. 10 LFR for the construction of 'ornemaniste'

As clearly demonstrated in Figures 8, 9 and 10, instances where agent nouns are formed from noun bases are accounted for in the generative LFR. Phonologically the rule takes part of the BL and adds the exponent (suffixes -ant, -eur and -iste) to each of the corresponding bases. Unlike in the first two scenarios, the Surface category here is a noun 
which is projected by the D-S. Since there is no projectable verb from the D-S, the morphological operation has to settle for the noun 'ornement', for instance, to serve as the $\mathrm{BL}$ on the surface for the formation of 'ornemaniste'. Agentivity is here justified because there is a subject in the D-S that performs a perceptible and social activity. This subject is an agent and it corresponds to 'ornemaniste' the eventual CL.

There is the forth situation where an adjective serves as a BL. Though a very rare scenario, the suffix -iste shows that there are few agent nouns with adjectival bases. In Figure 11, the LFR is applied to 'moderniste', which is an example of agent nouns with an adjectival base:

\begin{tabular}{|c|c|c|}
\hline & $\overline{\text { INPUT }}$ & OUTPUT \\
\hline $\bar{G}$ & modern & moderniste \\
\hline $\mathrm{F}$ & $/ \bmod \varepsilon n /$ & /modenist/ \\
\hline SX & Cat-Surf: Adj & Cat: $\mathrm{N}$ \\
\hline S & $\begin{array}{l}\text { D-S: l'homme défend les choses } \\
\quad \text { modernes } \\
\text { Role: } \mathrm{NP}=\text { Agent } \\
\text { +activity } \\
\text { (+perceptible, }+ \text { +social) }\end{array}$ & $\begin{array}{l}\text { Role: } \mathrm{NP}=\text { Agent } \\
\text { +agent } \\
\text { (+animate) }\end{array}$ \\
\hline
\end{tabular}

Fig. 11 LFR for the construction of 'moderniste'

In Figure 11, the adjective 'modern' is the projected BL on the surface. However, the D-S should be something like 'l'homme défend les choses modernes' (the man defends modern things). It is the D-S that actually makes the agent noun 'moderniste' possible because it would have been unimaginable for an adjective to serve as a BL for the construction of an agent noun. Having applied the lexeme-based rule on all possible scenarios of the -ant, -eur and -iste agent noun architecture, it is pertinent to show the possible weaknesses of the morpheme-based rule in some of these scenarios.

\section{THE PROBLEM WITH MORPHEME-BASED MORPHOLOGICAL ANALYSIS}

Simply looking at the analyses done above, a morpheme-based morphologist may advance the argument that MBM can also account for the formation of all the nine agent nouns analyzed in the previous section. Of course, the words in question can be morphemically analyzed but there will certainly be gaps in a few cases. Morpheme-based rules are like phrase structure rules which are predicated on the combinability of formatives. So, the nine complex words fabricant, délivreur, aliéniste, aboyant, valser, arabisant, adducteur, ornemaniste and moderniste will be analyzed in a syntactic manner as can be seen in Figure 12: 

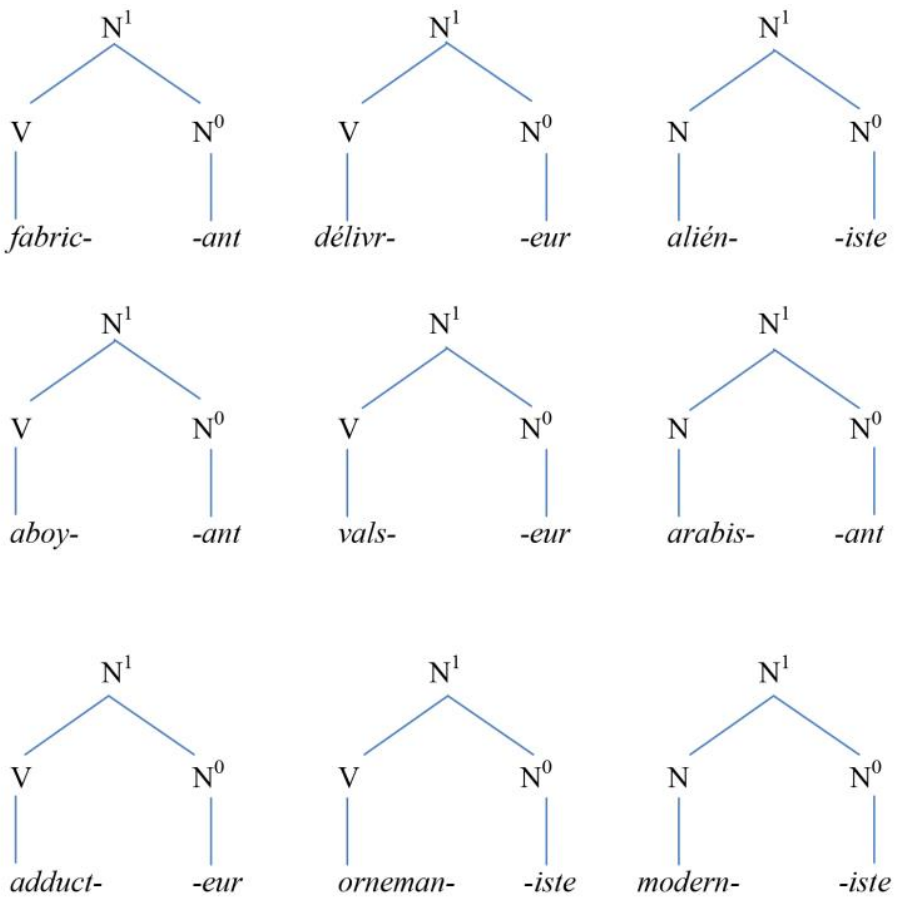

Fig. 12 Morpheme-based rule applied to fabricant 'délivreur', 'aliéniste', 'aboyant', 'valseur', 'arabisant', 'adducteur', 'ornemaniste' and 'moderniste'

On the surface, the isomorphic analyses in Figure 12 look simple and more straightforward than the preceding multidimensional lexeme-based treatment. However, there are gaps. The fundamental principle of MBM is that complex words are made up of biunique morphemes which are decomposable. Going by that principle, for instance, the morphemes délivr and eur should be able to stand alone with separate sound and meaning. Though each has a distinct sound, only the suffix eur can be said to be meaningful to some extent even as it cannot be listed in the dictionary as having a meaning. The same reasoning goes for the other eight pairs of morphemes. If we must argue along the line of free and bound morphemes, then it will mean that the morphemes forming each of the nine words are all bound morphemes. Why the LBM sounds more appropriate is the fact that to construct délivreur, for instance, the abstract lexeme is délivrer, from which complex lexemes such as délivreur are constructed through a multidimensional operation involving autographic, phonological, syntactic and semantic properties to which speakers of French have recourse mentally in producing words that are morphologically traceable to délivrer.

Another very critical flaw of the MBM as regards the formation of words with the suffixes -ant, -eur and -iste is its lack of accountability when base modification is involved. For instance, while the LFR, as earlier applied in this study, will conveniently account for the construction of -ant words such as fabricant (manufacturer) formed from the verb fabriquer (to manufacture), morphemic rules will find it difficult to account for how fabric-becomes the base morpheme to which the suffix - ant is added. 
As can be seen from the analyses of délivreur, valseur and aliéniste above, most of the ant, - eur and -iste nouns formed from verbs are constructed by simply taking the stem of the verbs as a base and then adding the suffix without any phonological modification. In the case of fabricant, the base mutates from fabriqu- to fabric-. This mutation is not a problem to a lexeme-based rule practitioner since the phonological issue involved in the stem metamorphosis is accounted for in the processes involved. Of course, the morpheme-based morphologist will argue that the principle of allomorphs has taken care of the phonotactic permutations in both derivational and inflectional morphological operations. However, the multidimensionality of lexeme-based rules accounts for those phonotactic permutations better as they are seen to be mental operations which have been captured by the phonological dimension of the rule. The construction of ornemaniste is another example in which there is interplay of base modification. Whereas the base is the noun ornament, the same base becomes orneman- in the construction process. Although this type of base modification may not be a phonological issue in French, there is surely an orthographical concern which is accounted for in a lexeme-based rule.

\section{CONCLUSION}

In this paper, we have applied what could be termed a generative LFR to the morphological construction of agent nouns in French using the agentive -ant, -eur and iste suffixations as a case study. The issue in the paper is to the effect that lexeme-based approaches to the analysis of morphologically constructed words yield better results than morpheme-based orientations. Particularly, the recourse made to the Morphological Deep Structure Hypothesis by Owoeye (2013) in the modeling of LFR proved to be outstanding and fruitful because the approach enabled us to account for all possible agentive formations in French using suffix -ant, -eur and -iste regardless of the syntactic category of the base lexeme. Not only that, we have also shown that base modification which is both phonologically and autographically conditioned and which is one of the many troubles of MBM has been systematically captured by the multidimensionality of the lexeme-based rules. Evidently, though the analyses carried out in this study are essentially limited to just three suffixes in French, we are of the opinion that if the LFR used for our analyses in this work is applied to word formation in other languages, there could be fruitful results as well. This is because, as remarked by Cutler (1977: 12), linguistic studies specifically carried out on a language could have universal implications.

\section{REFERENCES}

Anscombre, J.C., (2003), “L'agent ne fait pas le bonheur : agentivité et aspectualité dans certains noms d'agent en espagnol et en français", Thélème, Revista Complutense de Estudios Franceses : pp. 11-27

Aronoff, M., (1976), Word Formation in Generative Grammar, Linguistic Inquiry. Monograph One, Massachusetts, The MIT Press.

Booij, G., (1986), "Form and meaning in morphology: The case of Dutch agent nouns", Linguistics 24: pp. 503-517.

Cruse, D.A., (1973), "Some Thoughts on Agentivity" Journal of Linguistics 9: pp.11-23

Cutler, A., (1977)," The comparative perspective on spoken-language processing", Speech Communication 21: pp. $3-15$

Dowty, D.R., (1991), “Thematic Proto-Roles and Argument Selection”, Language 67, 3: pp. 547-619

Dubois, J., (1962), Etude sur la dérivation suffixale en français moderne et contemporain, Paris, Larousse.

Dubois, J., and Dubois-Charlier, F., (1999), La dérivation suffixale en français, Paris, Nathan. 
Dubois, J., Mitterand, H. and Dausat., A., (2006), Dictionnaire étymologique et historique du français, Paris, Larousse. Fillmore, C.J., (1968), "The Case for Case”, In Harms, R.T., Bach, E. and Fillmore, C.J. (eds) Universals in Linguistic Theory, New York, Academic Press.

Fillmore, C.J., (1982), "Frame semantics", Linguistics in the Morning Calm Vol.3 no.5: pp.111-137

Foley, W.A., and Van Valin, R., (1984), Functional Syntax and Universal Grammar, Cambridge, Cambridge University Press.

Fradin, B., (2003), Nouvelles approches en morphologie, Paris, Presses Universitaires de France.

Fradin, B., Kerleroux, F., (2003), Quelle base pour les procédés de la morphologie constructionnelle ? In Fradin, B., Dal, N.H., Kerleroux, F., Plénat, M. and Roché, M. (éds) Les unites morphologiques vol. 3 : pp. 76-84.

Grevisse, M., (1993), Le Bon usage $13^{\mathrm{e}}$ édition revue, Paris, Duculot.

Hockett, C.F., (1954), “Two Models of Grammatical Description”, Word 10: pp. 210-234

Laporte, E. (1992), “Adjectifs en -ant dérivés de verbes”, Langue francaise 96 : pp. 30-43

Matthews, P.H., (1974), Morphology. an Introduction to the Theory of Word-Structure, Cambridge, Cambridge University Press.

Owoeye, S. T., (2013), "La structure profonde et la modélisation des règles de construction de lexèmes : l'exemple de cinq suffixes agentifs du français", Linguistik Online 60 : pp. 43-58

Roché, M., (2007), "Logique lexicale et morphologie : la dérivation en -isme", In Montermini, F., Boyé, G. and Hathout, H., (eds) Selected Proceedings of the 5th Décembrettes: Morphology in Toulouse, Somerville : Cascadilla. pp. 45-58.

Rosenberg, M., (2008), La formation agentive en français : les composés [VN/A/Adv/P $]_{N / A}$ et les dérivés $V$-ant, $V$-eur et $V$-oir(e), Doctoral thesis, Stockholm University.

Roy, I., and Soare, E., (2010), "Naming Participants in the Event -ant/-eur/-é French Nominals and Compositionality in Morphology", Table ronde nominalisations, Université de Paris VIII : https://hal.archives-ouvertes.fr/hal00723654 /document

Ulland, H., (1993), Les nominalisations agentive et instrumentale en français moderne, Berne, Peter Lang.

\section{IZUČAVANJE AGENTIVNIH SUFIKSA -ANT, - EUR I -ISTE U FRANCUSKOM JEZIKU NA OSNOVU LEKSEMA}

Konstrukciona morfologija, koja ubrzano postaje alternativa derivacionoj morfologiji, zasnovana je na morfologiji leksema i značajna je zbog pravila tvorbe leksema koja se formulišu kako bi se objasnila tvorba postojećih derivacionih reči koje služe kao modeli za tvorbu drugih mogućih reči u jeziku. Razvoj morfologije leksema je rezultat nemogućnosti modela zasnovanim na morfemama da tačno objasne neke izvedene reči. Zagovornici morfologije leksema, stoga, smatraju da je pogodnije analizirati morfološki izvedene reči kada se lekseme uzimaju kao osnovne jedinice morfološke operacije. U svetlu ove hipoteze, $u$ ovom radu ćemo ispitati agentivne sufikse -ant-eur $i$-iste $u$ franscuskom jeziku da bismo istražili njenu analitičku adekvatnost. Nakon analize utvrdili smo da je pristup konstrukcionoj morfologiji zasnovan na leksemama adekvatniji nego pristup zasnovan na morfemama.

Ključne reči: leksema, morfologija leksema, agentivne imenice, pravilo tvorbe leksema, modifikacija osnove, francuski jezik 